\title{
Técnica para reconstrução de membros de doadores de tecidos osteomusculares*
}

\section{A Technique for the Reconstruction of the Limbs of Osteomuscular Tissue Donors}

\author{
Luiz Roberto Gomes Vialle ${ }^{1}$ Emiliano Neves Vialle ${ }^{1}$ Felipe de Negreiros Nanni ${ }^{1 \odot}$ \\ ${ }^{1}$ Serviço de Ortopedia e Traumatologia, Hospital Universitário Cajuru, \\ Pontifícia Universidade Católica do Paraná, Curitiba, PR, Brasil
Endereço para correspondência Felipe de Negreiros Nanni, MD, Rua Coronel Dulcídio, 1205, apto 11, Curitiba, PR, Brasil. CEP 80250-100 (e-mail: felipe_nanni@hotmail.com).

Rev Bras Ortop 2020;55(1):112-114.

\section{Resumo \\ Palavras-chave \\ - obtenção de tecidos e órgãos \\ - transplante ósseo \\ - reconstrução \\ - bancos de ossos}

A doação de tecidos ósseos e tendíneos é uma importante fonte de material biológico empregado em diversas técnicas cirúrgicas. A remoção destes tecidos gera uma importante sequela estética no doador, sendo necessária a reconstrução dos membros antes da devolução do corpo aos familiares. A técnica utilizada pelo Banco de Ossos do Paraná faz uso de vergalhões metálicos, tubos de silicone e abraçadeiras de náilon para reconstruir os membros, uma técnica de fácil execução e com resultado estético satisfatório.

The donation of bone and tendon tissues is an important source of biological material used in various surgical techniques. The removal of these tissues generates an important aesthetic sequel in the donor, being necessary the reconstruction of the members before the return of the body to the relatives. The technique used by the Bank of Bones of Paraná makes use of metallic rebar, silicone tubes and nylon clamps to rebuild the limbs, a technique of easy execution and with satisfactory aesthetic result.

\section{Introdução}

A doação de tecidos ósseos e tendíneos representa uma importante fonte de material biológico para diversas técnicas de transplante de tecido, seja como enxertos estruturados ou componentes de osteoindução.

A doação de tecidos musculoesqueléticos demanda um extenso procedimento de captação com a remoção de diversas estruturas ósseas, musculares e tendíneas de membros inferiores e superiores.

\footnotetext{
Trabalho feito no Grupo de Cirurgia de Coluna, Serviço de Ortopedia e Traumatologia, Hospital Universitário Cajuru, Pontifícia Universidade Católica do Paraná, Curitiba, PR, Brasil.
}

recebido

08 de Janeiro de 2018

aceito

14 de Agosto de 2018
DOI https://doi.org/

10.1055/s-0039-1692696. ISSN 0102-3616.
A remoção destas estruturas cria uma sequela estética, que demanda a reconstrução do cadáver tanto em respeito aos familiares do doador quanto do ponto de vista legal.

A Lei $n^{\circ} 10.211$ de 23 de Março de 2001 preconiza que o cadáver do doador deve ser condignamente recomposto para ser entregue aos parentes ou responsáveis legais para o sepultamento.

A falta de compreensão do procedimento de reconstrução do cadáver após a captação de ossos é um dos principais responsáveis pela recusa dos familiares à doação de tecidos osteomusculares. Um estudo demonstrou que $96.2 \%$ dos familiares que recusaram a doação não possuía conhecimento de como seria feita a reconstrução e como o corpo seria apresentado após o procedimento. ${ }^{1}$

Copyright $\odot 2020$ by Sociedade Brasileira License terms de Ortopedia e Traumatologia. Published by Thieme Revnter Publicações Ltda, Rio de Janeiro, Brazil 


\section{Outros Métodos}

Existem diversos métodos utilizados para a reconstrução de membros após a captação de ossos, sendo o mais comum a utilização de sistemas compostos de tubos de PVC ou madeira, ${ }^{2}$ que simulam a estrutura óssea prévia do paciente.

Esses sistemas, porém, possuem alguns inconvenientes. São sistemas que possuem peças volumosas, que demandam grandes caixas para a acomodação e transporte. A mobilização das equipes de captação muitas vezes se dá através de aviões de pequeno porte com espaço de carga reduzido, contando com poucas pessoas para o transporte dos materiais, fazendo com que sistemas de maior volume e peso se tornem inconvenientes.

Outra desvantagem desses sistemas é que muitas vezes as peças possuem acabamento de grande diâmetro e difícil encaixe nas estruturas ósseas do doador. Existem sistemas pré-fabricados que eliminam este problema, porém possuem um custo elevado que acaba por inviabilizar seu uso.

\section{Método utilizado pelo Banco de Ossos do Paraná}

A equipe do Banco de Ossos do Paraná desenvolveu um sistema de reconstrução dos sítios doadores que visa eliminar a problemática do transporte dos componentes e a dificuldade de adaptação.

A técnica consiste no uso de vergalhões metálicos de $15 \mathrm{~mm}$ de diâmetro previamente cortados e moldados, tubos de silicone e abraçadeiras de Nylon (-Fig. 1).

\section{Reconstrução de Membros Superiores}

Nos membros superiores é costumeiramente realizada a captação do úmero, do rádio e da ulna.

Para a reconstrução de membros superiores, utiliza-se uma haste metálica de $30 \mathrm{~cm}$ com o terço proximal prémoldado em um ângulo de $135^{\circ}$ para substituição estrutural do úmero, uma haste metálica de $30 \mathrm{~cm}$ para reconstrução do

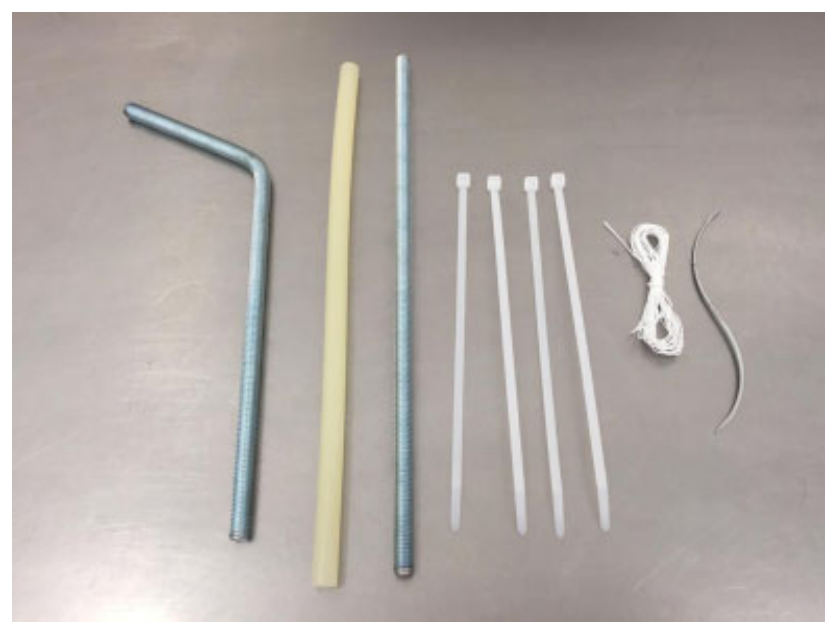

Fig. 1 Vergalhão metálico, tubo de silicone, abraçadeira de Nylon, fio de sutura e agulha de sutura em "S".

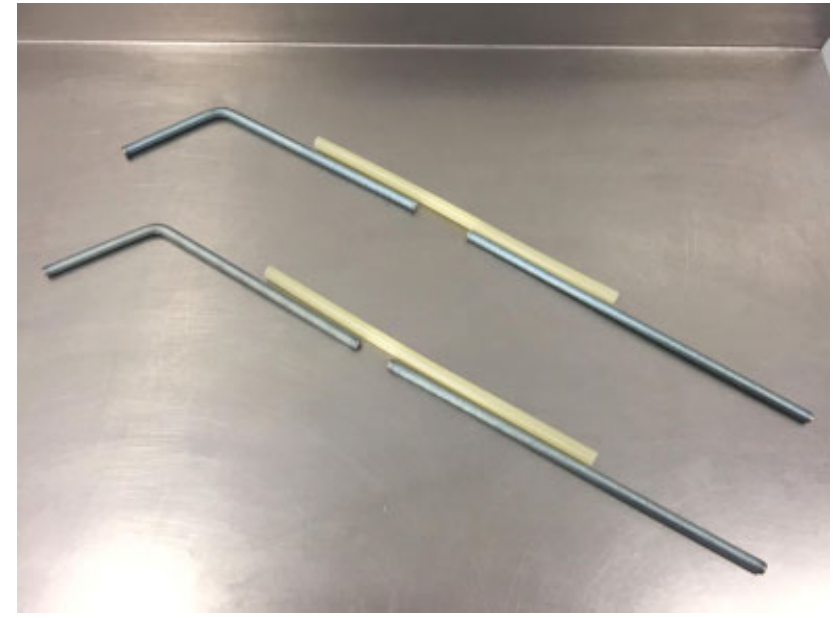

Fig. 2 Componentes de reconstrução dos membros superiores.

antebraço, e um tubo de silicone para recriar a articulação do cotovelo (-Fig. 2).

O membro superior é costumeiramente visível em cerimônias funerárias, portanto, um membro reconstruído de maneira a permanecer articulável possibilita uma melhor preparação do corpo do doador para a cerimônia.

Um orifício é criado com auxílio de formão e martelo na glenóide, e então o componente umeral é martelado de maneira a se encaixar firmemente. Uma compressa cirúrgica é então inserida no espaço da cabeça umeral para conferir maior estabilidade da montagem.

O componente do antebraço é encaixado entre os ossos do carpo e ambos são unidos na região do cotovelo ao tubo de silicone, através de abraçadeiras de náilon (-Fig. 3 ).

Os componentes individuais permitem uma montagem que se adapte ao tamanho do membro do doador, permitindo grande liberdade de reconstrução com apenas um único tamanho padrão.

Devido à diferença volumétrica das estruturas ósseas retiradas e das hastes metálicas empregadas na reconstrução, faz-se o uso de compressas cirúrgicas em torno das hastes para aumentar seu volume, sendo que ao fechar a pele com fio de algodão, a compressão exercida pela pele acaba

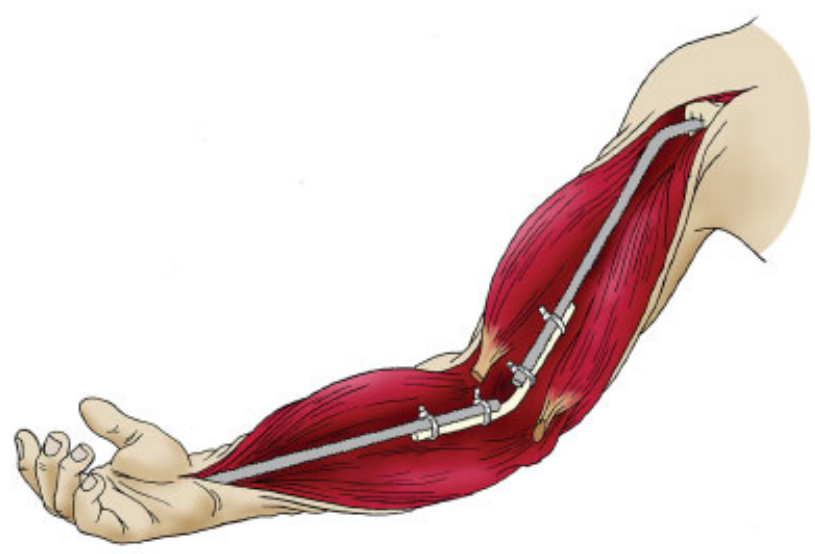

Fig. 3 Estrutura interna do membro superior montada. 
114 Técnica para reconstrução de membros de doadores de tecidos osteomusculares Vialle et al.

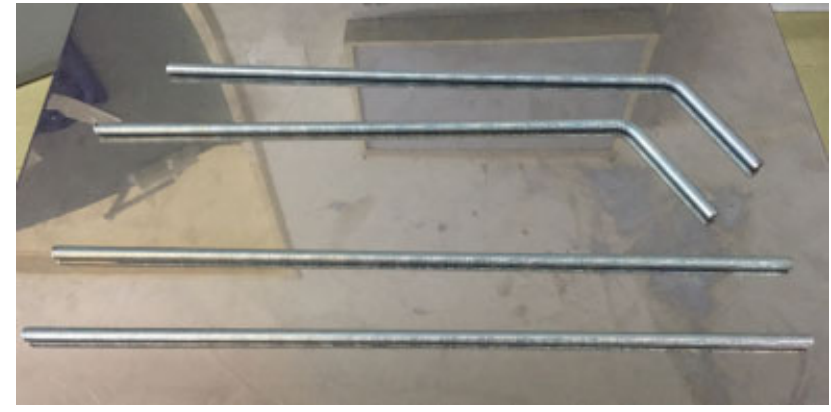

Fig. 4 Componentes de reconstrução de membros inferiores.

por ajudar a moldar o formato do membro, conferindo um aspecto esteticamente agradável.

Os membros são então enfaixados com ataduras de crepe.

\section{Reconstrução de Membros Inferiores}

Nos membros superiores, é costumeiramente realizada a captação do fêmur, da tíbia, da fíbula, do tálus, do tendão quadricipital e patelar (conjuntamente à patela) e do tendão aquileu.

Para a reconstrução de membros inferiores, utiliza-se uma haste metálica de $50 \mathrm{~cm}$ com o quinto proximal pré-moldado em um ângulo de $135^{\circ}$ para a substituição estrutural do fêmur e uma haste metálica de $55 \mathrm{~cm}$ para a reconstrução da perna (-Fig. 4).

Um orifício é criado com auxílio de formão e martelo no acetábulo, e então o componente femoral é martelado de maneira a se encaixar firmemente. Uma compressa cirúrgica é firmemente adaptada no acetábulo para conferir uma maior estabilidade da montagem.

Um segundo orifício é criado com auxílio de formão e martelo na face articular anterior do calcâneo, onde é adaptado com auxílio de martelo o componente responsável pela reconstrução da perna.

Os componentes individuais permitem uma montagem que se adapte ao tamanho do membro do doador, sendo importante atentar para a simetria do comprimento de membros inferiores antes de fixar os componentes com as abraçadeiras de náilon (-Fig. 5).

A diferença volumétrica após a retirada das estruturas ósseas e tendíneas é ainda mais evidente nos membros inferiores, sendo necessária a utilização de um número maior de compressas cirúrgicas, principalmente na região do joelho, para obter-se um resultado esteticamente aceitável.

Após a sutura da pele com fio de algodão, os membros são então enfaixados com ataduras de crepe individualmente e então ambos são enfaixados juntos de maneira a manter os membros inferiores em rotação neutra.

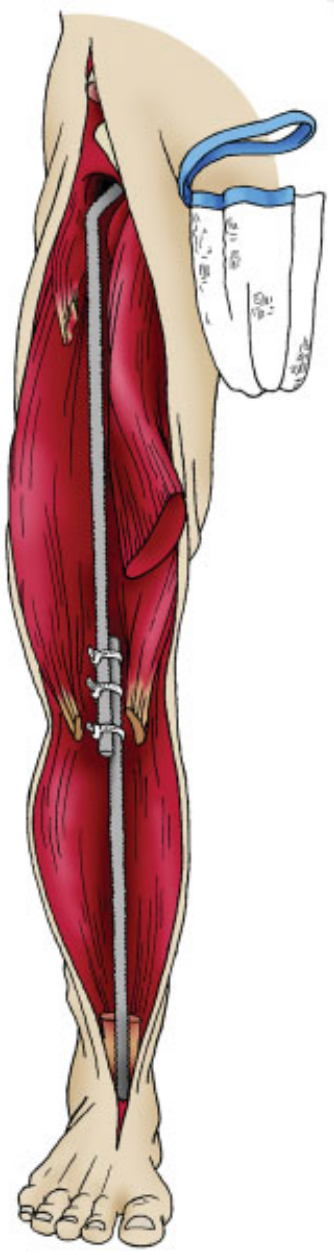

Fig. 5 Estrutura interna do membro inferior montada.

\section{Conclusão}

O método de reconstrução de membros de doadores de tecidos musculoesqueléticos desenvolvido pelo Banco de Ossos do Paraná apresenta-se como uma opção de baixo custo, versatilidade no transporte e bom resultado estético.

Conflito de Interesses

Os autores declaram não haver conflito de interesses.

\section{Referências}

1 Pompeu MH, Silva SS, Roza BA, Bueno SM. Factors involved in the refusal to donate bone tissue. Acta Paul Enferm 2014;27(04): 380-384

2 de Alencar PG, Vieira IF. Banco de ossos. Rev Bras Ortop 2015;45 (06):524-528 